\title{
Vài nét khái quát về độc giả văn học miền Nam 1954-1975
}

\section{Lê Quốc Hiếu*}

Tóm tắt: Dưới tác động của bối cảnh văn hóa và chính trị giai đoạn 1954-1975, giới cầm bút và độc giả văn học miền Nam hình thành nhiều khuynh hướng đa dạng. Khác với độc giả của văn học hiện thực xã hội ở miền Bắc, độc giả văn học miền Nam là các nhóm thực thể không đồng nhất về giai cấp xã hội, ý thức hệ và thị hiếu thẩm mĩ. Bài viết tập trung khảo sát hai kiểu độc giả chính yếu và sinh hoạt sôi nổi nhất ở miền Nam: độc giả của văn học thị trường và độc giả của văn học nghệ thuật. Những tác động của xã hội đến sinh hoạt văn nghệ và khuynh hướng thẩm mĩ, mãi lực của độc giả cũng được tìm hiểu trong bài viết này.

Tù khóa: độc giả văn học; văn học miền Nam; 1954-1975; văn học thị trường; văn học nghệ thuật.

Ngày nhận 16/10/2020; ngày chỉnh sửa 29/4/2021; ngày chấp nhận đăng 30/6/2021

DOI: https://doi.org/10.33100/tckhxhnv7.3.LeQuocHieu

\section{Mở đầu}

Sau 9 năm kháng chiến gian khổ (19451954) nhân dân Việt Nam đã lật đổ chế độ thực dân Pháp, khép lại một trang sử hào hùng của dân tộc. Hiệp định Genève về Đông Dương được ký kết vào ngày 21/7/1954. Các nước tham dự hội nghị này đã cam kết tôn trọng độc lập, chủ quyền, thống nhất và toàn vẹn lãnh thổ của ba nước Đông Dương; Ngừng bắn toàn cõi Đông Dương; Lấy vĩ tuyến 17 làm giới tuyến quân sự tạm thời; Pháp rút khỏi Đông Dương và mỗi nước Đông Dương sẽ bầu cử tự do, v.v.. Được sự ủng hộ của Mỹ, chính quyền $\mathrm{Ngô}$ Đình Diệm được dựng lên ở miền Nam Việt Nam. Một thiết chế quân sự, chính trị và văn hóa mới được hình thành với những chính sách khác nhau nhằm biến miền Nam Việt Nam trở thành một quốc gia mới, do đó, làm biến đổi xã hội miền Nam trên nhiều

\footnotetext{
*Viện Văn học, Viện Hàn lâm Khoa học xã hội Việt Nam; email: hieu.lequoc@gmail.com
}

phương diện. Các đặc điểm về bối cảnh văn hóa xã hội của giai đoạn 1954-1975 đều trực tiếp hoặc gián tiếp tác động đến sinh hoạt văn nghệ và diện mạo của độc giả văn học.

\section{Chính sách của Mỹ đối với văn hóa và văn học ở miền Nam}

Về cơ bản, xã hội miền Nam từ sau năm 1954 chịu ảnh hưởng từ nhiều nền văn hóa: văn hóa Trung Hoa, văn hóa châu Âu (nhất là văn hóa Pháp hiện diện ở miền Nam khoảng một thế kỉ) và văn hóa Mỹ. Có thể nói, chính sách giáo dục là yếu tố tiên quyết có ảnh hưởng đển diện mạo của công chúng văn học. Sau Hiệp định Genève, bên cạnh việc di chuyển các lực lượng quân sự, dân sự từ miền Bắc vào miền Nam, việc chuyển dịch các thiết chế văn hóa, giáo dục được Pháp và Mỹ tiến hành khẩn trương. Cụ thể là, dưới chính thể Quốc gia Việt Nam, chi nhánh của Viện Đại học Đông Dương ở Sài Gòn được tái cơ cấu thành Viện Đại học 
Quốc gia Việt Nam, và từ sau năm 1957, được đổi tên thành Viện Đại học Sài Gòn. Các phân ngành khoa học xã hội và nhân văn được chú trọng đào tạo. Giáo dục đại học là chính sách quan trọng nhằm đào tạo đội ngũ nhân lực dồi dào cho chế độ mới. Nếu trước đây, chỉ có duy nhất một viện đại học đào tạo nhân lực cho toàn Đông Dương thì tính đến sau năm 1964, bên cạnh hai viện đại học công (Sài Gòn, Huế), còn có thêm hai viện đại học tư (Đà Lạt và Vạn Hạnh). Nhìn chung, giáo dục đại học ở miền Nam (1956-1964) vẫn chịu ảnh hưởng nặng nề của giáo dục Pháp. Tuy nhiên, kể từ năm 1965, khi Mỹ trực tiếp đưa quân tham chiến ở chiến trường miền $\mathrm{Nam}$, văn hóa $\mathrm{Mỹ}$ và lối sống Mỹ theo đó mà "ùa tràn" vào đời sống miền Nam Việt Nam. Từ đây, giáo dục đại học được cải tổ theo mô hình của Mỹ (điển hình là chế độ đào tạo theo tín chỉ). Ngân sách giáo dục của Chính quyền Việt Nam cộng hòa $(\mathrm{VNCH})$ cho các trường, viện đào tạo không nằm ngoài mục đích xây dựng một hệ thống giáo dục con người, phục vụ cho chủ nghĩa thực dân mới của Mỹ ở miền Nam Việt Nam.

Thông thường, một trong những chiến lược văn hóa của đế quốc thực dân đối với thuộc địa là làm cho người dân thuộc địa nhận thức về thời kì tiền thuộc địa của dân tộc họ "như là một trạng thái lơ lửng tiền khai hóa" (precivilised limbo) hoặc "một khoảng trống lịch sử" (historical void) (Barry 2009: 186). Muốn vậy, quốc gia xâm lược phải làm cho người dân thuộc địa quên đi quá khứ, lịch sử và bản sắc văn hóa dân tộc thông qua việc kiến tạo nên một nền văn hóa mới được mẫu quốc hậu thuẫn. Các sản phẩm văn hóa vật chất và tinh thần (hàng hóa Mỹ, kĩ thuật Mỹ, phim ảnh, băng nhạc, đĩa hát, tranh ảnh, tivi, sách báo, v.v.) được công khai tiêu dùng và hỗ trợ nhập cảng miền Nam Việt Nam.
Ở miền Nam, sự xuất hiện phong phú các hệ thống nhà xuất bản, tạp chí, dòng phái, khuynh hướng văn học cho thấy nhu cầu thẩm mĩ đa dạng của độc giả, và tính năng động, tự do của thị trường tiêu thụ. Bên cạnh đó, có nhiều tờ báo với các thái độ văn hóa, chính trị khác nhau cùng hoạt động: thân chính phủ chống Cộng hoặc ngược lại; Chính trị hóa hoặc phi chính trị; Văn học thuần khiết hoặc "văn học trong vòng tay chính trị”" (Nguyễn Văn Trung 2001: 15). Các tiếng nói đối lập với chính quyền $\mathrm{VNCH}$ vẫn được đăng đàn trên báo chí đương thời, ví dụ, hai tờ báo chống tham nhũng nổi tiếng Tin sáng và Sóng thần, đối đầu công khai với chính phủ VNCH (Nguyễn Quang Duy 2015; BBC 2018).

Ngoài ra, còn phải kể đến một số thiết chế văn hóa văn học khác có vai trò chi phối hoạt động sáng tạo, xuất bản, và tiếp nhận văn chương. Có thể liệt kê một số hội đoàn văn học được thành lập có ảnh hưởng lên sinh hoạt văn học như: Hội Văn hóa Việt Nam, Mặt trận văn hóa tự do, Hội Khổng học, Hội Văn hóa bình dân, Liên đoàn Văn nghệ sĩ, Hội Cổ học, Hội Văn hữu, Tinh Việt văn đoàn, v.v.. Hoạt động của các nhóm độc giả cùng sinh hoạt và sáng tác văn chương như: Sáng tạo, Quan điểm, Vấn đề, Trình bày, nhóm Quỳnh Dao, v.v. đã góp phần mang lại cho sinh hoạt văn chương một không khí sôi nổi, đa dạng. Hoạt động có hiệu quả hơn cả phải kể đến Trung tâm Văn bút Việt Nam. Trung tâm đã tổ chức nhiều cuộc trò chuyện văn chương, đàm luận nghệ thuật, trao giải thưởng văn học. Nhìn chung, hoạt động đa dạng của các nhóm phái văn học này được vận hành trên tinh thần ít nhiều tự do, "trăm hoa đua nở" ở miền Nam. Bên cạnh sự hiện diện của các nhà xuất bản, hệ thống báo chí và trung tâm học thuật, các giải thưởng văn chương cũng góp phần chi phối đến khuynh hướng thẩm 
mĩ, nhu cầu đọc và mãi lực (sức mua) của độc giả.

Ngoài một số chính sách văn hóa nói trên, văn hóa đọc của độc giả miền Nam còn chịu ảnh hưởng mạnh mẽ từ những thay đổi chóng vánh của các thể chế chính trị văn hóa, quy luật thương mại hóa văn nghệ, khói lửa chiến tranh tràn vào đời sống sinh hoạt, cơn lốc gia tăng của thuế khóa và vật giá in ấn, v.v..

\section{Cơ cấu của độc giả văn học miền Nam 1954-1975}

Dưới tác động của bối cảnh văn hóa thời đại, giới cầm bút và độc giả văn học miền Nam hình thành nhiều khuynh hướng đa dạng từ "cực hữu đến cực tả, từ viễn mo, hưởng thụ đến quá khích, tranh đấu ôn hòa, xây dựng, v.v." (Phạm Việt Tuyển 1972: 9). Văn học miền Nam chứng kiến sự hình thành đa dạng của các nhóm phái, tư tưởng khác nhau với những đối tượng độc giả riêng, tùy thuộc vào thái độ chính trị của họ. Một số khuynh hướng văn học nổi bật như: Khuynh hướng yêu nước chống thực dân Pháp, đế quốc Mỹ; Khuynh hướng văn hóa văn học bị dán nhãn là "đồi trụy, phản động"; Khuynh hướng tìm về văn hóa dân tộc; Khuynh hướng đứng ngoài lề, thực hành văn học thuần túy, đi sâu vào mô tả phong tục, tâm lí, và đời sống thường ngày; Khuynh hướng thực hành triết học, tôn giáo qua văn chương; Khuynh hướng văn chương tiêu thụ, v.v.. Do đó, khác với độc giả quần chúng của văn học hiện thực xã hội ở miền Bắc, độc giả văn học miền Nam là các nhóm thực thể không đồng nhất về thành phần giai cấp xã hội, ý thức hệ, và khuynh hướng thẩm mĩ. Bài viết tập trung khảo sát hai kiểu độc giả chính yếu và sinh hoạt có phần sôi nổi nhất ở miền Nam: độc giả của văn học thị trường và độc giả của văn học nghệ thuật. Việc phân chia cơ cấu của độc giả thành hai bộ phận nói trên cũng phù hợp với ý hướng của độc giả văn học nói chung. Nhà văn Thạch Lam khi luận bàn về người đọc tiểu thuyết đã phân chia người đọc thành hai hạng: hạng độc giả chỉ cốt xem truyện và hạng độc giả thích suy nghĩ (Thạch Lam 1941: 33).

\section{1. Độc giả của văn học thị trừ̀ng}

\subsubsection{Văn hoc thị trường là gì?}

Thuật ngũ "văn học thị trường" (massmarketed literature) có một nội hàm khái niệm khá lỏng lẻo. Báo chí văn hóa văn nghệ miền Nam còn sử dụng nhiều thuật ngữ khác nhau như: "văn học tiêu thụ", "văn học giải trí", "văn học bình dân", v.v. để định danh cho một khuynh hướng văn học đề cao tính giải trí, tính lợi nhuận, và tính đại chúng. Văn chương trở thành thương phẩm, do đó, mãi lực của độc giả là mục tiêu và thước đo cho sự thành công của dòng văn học thị trường. Muốn vậy, tác phẩm phải hướng đến tính giải trí, tính dễ đọc (legibility) và tính đại chúng. Văn học thị trường ở miền Nam chịu sự chi phối của các diễn ngôn thống soát của từng thời kì, các thiết chế văn hóa xã hội được xây dựng dựa trên các quan hệ kinh tế tư bản như nhà xuất bản, nhà in, nhà phát hành, nhà sách, báo chí, quảng cáo, phê bình, v.v.. Tất cả những yếu tố trên đã tác động, ở các mức độ khác nhau lên sinh hoạt văn chương và nhu cầu thẩm mĩ của độc giả.

Tuy nhiên, cách định danh văn học "thị trường", "tiêu thụ", "giải trí", "bình dân" đã "ẩn chứa một thái độ kỳ thị, một cảm xúc tiêu cực" (Võ Văn Nhơn và cộng sự 2015: 91), có phần hạ thấp giá trị tinh thần, chức năng giải trí của tác phẩm, đồng thời làm xa lạ hóa bản chất nguyên thủy của tiểu thuyết: giải trí, mua vui. Một định nghĩa có tính kinh điển về văn chương tiêu thụ thường xuất hiện trong các bài viết về văn học thị 
trường miền Nam (Lữ Phương 1967; Võ Văn Nhơn và cộng sự 2015; Huỳnh Như Phương 2015) là của Sơn Nam": "Đó là loại kẹo ngọt, loại bông hường bằng ni-lon... ba món ăn chơi. Độc giả tiêu thụ hấp tấp, đọc để tìm hiểu cốt chuyện, không câu nệ về cách hành văn, chính tả, cách chấm câu. Đọc rồi là họ quên ngay, quên cả tựa quyển sách, “sã̃n sàng bán ve chai" (Lữ Phương 1967: 114). Bản thân định nghĩa này đã hàm ý một thái độ coi thường các kiểu loại văn chương thiên về/ chỉ để "mua vui", "giải trí". Mặc dù, trên thực tế, rất nhiều tiểu thuyết thị trường được in ấn nhanh chóng, cẩu thả, dễ dãi theo hình thức feuilleton (tiểu thuyết đăng báo nhiều kỳ) để thỏa mãn cấp tốc nhu cầu giải trí, tò mò của độc giả.

\subsection{2. Độc giả của văn học thị truờng là ai?}

Chủ thể tiêu dùng của văn học thị trường là thị dân, bán thị dân, đối tượng vừa tiêu thụ và vừa phục vụ quá trình tiêu thụ của xã hội miền Nam. Họ là một cộng đồng độc giả hồn tạp với đủ mọi giai cấp, địa vị, nghề nghiệp, và thái độ văn hóa, chính trị, v.v. khác nhau: tiểu thương, thợ thủ công, trí thức, tư sản, công nhân, nội trợ, v.v.. Tuy nhiên, thành phần độc giả đồng đảo nhất của văn học thị trường là bộ phận lao động thuộc giới bình dân thành thị. Họ trước đây chủ yếu là nông dân, có cơ hội được gia nhập và sinh hoạt văn nghệ là nhờ quá trình thành thị hóa người nông dân.

Nhìn chung, giới độc giả của văn học thị trường gắn chặt với nhật báo. Thói quen đọc nhật báo và mãi lực của họ quyết định sinh mệnh của một tờ nhật báo. Đó là lí do vì sao hầu hết các tác phẩm văn học giải trí, thị trường trước khi được in thành sách, chúng đều có tiền kiếp của chúng ở dạng feuilleton trên các nhật báo. Vấn đề này đã được Thanh Nam lí giải như sau: “...thành phần độc giả của các báo hàng ngày cũng như hàng tuần ở Sài Gòn đa số thuộc giới bình dân, lao động, những bà những cô bán hàng ngoài chợ. Khác hẳn ngoài Bắc, giới lao động trong Nam rất chịu mua báo, đọc báo. Ở Hà Nội, người ta không thể nào bắt gặp một anh xích lô ghếch mũi xe vào một hè đường vắng, dưới bóng cây râm mát nằm khểnh trên nệm, phì phèo điếu thuốc, đọc báo suốt một buối trưa, từ chối chở khách, cũng như khó tưởng tượng được cái cảnh một bà bán cá trong chợ vừa trả lời giá cả với khách hàng vừa coi tiểu thuyết trong báo" (1982: 69).

\subsubsection{Thị hiếu thẩm mĩ của độc giả văn học thi truờng}

Thị hiếu thẩm mĩ của độc giả văn học thị trường xoay quanh hai đối tượng chính, truyện Tàu và truyện tình. Nhìn từ truyền thống tiếp nhận, hai kiểu văn chương thị trường này vốn là món ăn tinh thần của đại đa số người dân miền Nam ngay từ những năm đầu thế kỉ XX. Đặc điểm chung nhất của kiểu độc giả này đó là: i. Họ yêu thích, thậm chí là say mê các "sản phẩm" văn học trinh thám, hoang đường, dã sử, phiêu lưu, kiếm hiệp, chưởng, ái tình, v.v. bởi những thương phẩm này đã đáp ứng nhu cầu văn hóa, "mở ra một chân trời phong phú mênh mông hơn cuộc đời vô vị thường ngày" (Nguyễn Mộng Giác 1972b: 29) của độc giả thành thị; ii. Vì thế, đối với nhiều độc giả, thưởng thức văn học giải trí được xem như là một hành vi kháng cự lại/ vượt thoát khỏi thực tại đời sống ngột ngạt, chao đảo đang bao trùm toàn bộ miền Nam trong khoảng 20 năm.

\subsection{4. Độc giả say mê truyện Tàu}

Văn học giải trí giai đoạn này đáng chú ý nhất là các tiểu thuyết ăn khách: truyện anh hùng, hảo hán, dã sử Tam Quốc diễn nghĩa (La Quán Trung), Đông Chu liệt quốc (Sài Nguyên Phóng), truyện trinh thám của Sherlock Holmes, Conan Doyle, truyện kiếm hiệp Ba ngườ lính ngự lâm (A. Dumas 
père), truyện hoang đường Liêu trai chí di (Bồ Tùng Linh), truyện viễn tưởng Xúr người mù (H.G. Wells), truyện kinh dị Bàn tay máu của Phi Long (Ngọc Sơn), truyện võ hiệp kỳ tình $K \tilde{y}$ nũu Gò Ôn Khâu (Hoài Điệp Thứ Lang - nhà thơ Đinh Hùng), Lệnh xé xác (Lã Phi Khanh - Vũ Bình Thư), v.v.. Tuy nhiên, đáng chú ý nhất phải kể đến hiện tượng Kim Dung. Việc tiếp nhận Kim Dung vốn nằm trong truyền thống tiếp nhận truyện Tàu trước đó ở miền Nam. Độc giả miền Nam, nhất là độc giả nam giới, rất mê truyện Tàu (kiếm hiệp, truyện chưởng) thậm chí họ còn bị nhiễm nhân sinh quan của Tàu rất đậm (Bình Nguyên Lộc 1969: 13-14). Thú xem truyện Tàu (một tựa sách của Vương Hồng Sến) rất điển hình cho sinh hoạt văn học văn hóa trong 30 năm (1890-1920) ở miền Nam trước khi nó bị các tiểu thuyết của Nguyễn Chánh Sắt, Lê Hoằng Mưu, Hồ Biểu Chánh làm cho lụi tàn (Bình Nguyên Lộc 1969: 15). Năm 1961, dịch giả Từ Khánh Phụng với bản dịch Cô gái Đồ Long trên Báo Đồng Nai đã khởi mở đầu cơn sốt Kim Dung tại Việt Nam. Trong suốt giai đoạn 1965-1973, một cuộc chạy đua dịch thuật, phát hành truyện võ hiệp, truyện chưởng của Kim Dung, thậm chí sáng tác truyện "nhái" Kim Dung, "ăn theo" Kim Dung trên hầu hết nhật báo miền Nam. Cơn sốt Kim Dung còn kéo dài đến tận giai đoạn 1972-1974 khi bộ Lộc đỉnh ký được dịch và xuất bản (Nguyễn Văn Lục 2014). Có thể nói, sáng tác của Kim Dung là một hiện tượng văn học, văn hóa có tính dân tộc, xuyên dân tộc, và liên văn hóa, v.v. vượt ra khỏi những phạm trù/ thuật ngữ hạn hẹp thường định danh chúng: "Văn học đại chúng", "Văn học bình dân", "Văn học tiêu khiển", v.v..

Tác phẩm của Kim Dung là món ăn tinh thần của mọi giai tầng, giới tính, lứa tuổi khác nhau. Ở miền Nam, văn hóa đọc nhật trình, tiểu thuyết feuilleton, v.v. đã ăn sâu vào sinh hoạt hàng ngày của người lao động ở thành thị. Người đạp xích lô, tài xế taxi, giới tiểu thương cũng có thói quen đọc nhật trình những khi vắng khách. Theo Hiếu Chân, "không chỉ có những người trong đại chúng bình dân, những học sinh, thợ thuyền và tiểu công tư chức mà ngay cả những tay đại trí thức, những người đã từng du học bên Âu - Mỹ trở về, đã từng đỗ những mảnh bằng cao nhất về luật học hay khoa học cũng say mê võ hiệp tiểu thuyết như điếu đổ" (Trần Lê Hoa Tranh 2009). Chưa hết, theo Nguyễn Viết Khánh, các nhà tu hành cũng ham thích truyện chưởng của Kim Dung, "những ông bự và những ông đại sứ cho người về nước khuân hàng... thùng tài liệu Kim Dung để đem đi đọc ở xứ người. Các bà cũng thích chưởng. Giáo sư thảo luận với học sinh về chưởng. Trẻ em đánh nhau ngoài đường cũng dùng chưởng..." (Trần Lê Hoa Tranh 2009). Vậy điều gì làm nên sức hấp dẫn của Kim Dung đối với độc giả? Có thể thấy, Kim Dung đã xây dựng nên một thế giới võ lâm sống động với các tình huống lưỡng nan giữa chính - tà, thiện - ác, chính nghĩa - phi nghĩa, quá khứ - hiện tại, tình yêu - hận thù, và lý trí - tình cảm. Những bài học nhân văn về tình huynh đệ, tình phụ tử, tình sư đồ, v.v. được chuyển tải khéo léo, hấp dẫn, xúc động qua thế giới võ lâm. Tri thức uyên bác của Kim Dung về nhân tình thế thái, về văn hóa Trung Hoa nhất là lịch sử và võ hiệp, ngôn ngữ đậm tính bình dân có sức hấp dẫn đặc biệt với độc giả nhất là nam giới. Các nhân vật nữ trong tiểu thuyết võ hiệp của Kim Dung thường xinh đẹp, thông minh, tài năng và cá tính hoặc xuất thân từ tà ma ngoại đạo (ma giáo), hành tung và thân phận đầy bí ẩn, v.v. thường chiếm trọn cảm tình của độc giả nam giới. Tuy là tiểu thuyết võ hiệp, có vẻ đẫm sắc thái nam tính và hợp hơn với nam giới, nhưng không, về bản chất, cũng có thể coi tác phẩm của Kim Dung là những câu 
chuyện diễm tình đầy nữ tính. Kim Dung đã "đánh trúng" tâm lí của con người về/ trong tình yêu. Các mối tình đầy cắc co: chính phái yêu tà phái, bạch đạo yêu hắc đạo cùng với những hệ lụy của tình yêu - hận thù, ghen tuông - mù quáng, v.v. có sức hút đông đảo với độc giả nữ giới.

Những huyền thoại của văn hóa bình dân thoát thai từ truyện võ hiệp của Kim Dung đã "ăn sâu bén rễ”" trong tâm thức và sinh hoạt của người dân miền Nam. Các nam anh hùng - nữ mỹ nhân, chàng hào hoa - nàng diễm lệ, chính - tà, thiện - ác bước ra từ không gian truyện kể của Kim Dung để rồi hiện diện sinh động trong đời sống văn hóa Sài Gòn. Niềm say mê truyện chưởng Kim Dung lớn đến nỗi phong vị Kim Dung bàng bạc trong khẩu khí sinh hoạt đời thường của người dân miền Nam. Trong đời sống học thuật, tên các nhân vật của Kim Dung còn được một số học giả dùng làm bút danh: "Nhiều nhà văn từ việc mê chưởng đã lấy bút hiệu bằng tên một số nhân vật mà họ tâm đắc trong truyện Kim Dung. Chu Văn Bình, ngoài những bút hiệu Chu Tử, Ao Thả Vịt, v.v. còn lấy thêm bút hiệu Kha Trấn Ác (một trong Giang Nam thất quái trong Anh hùng $x a$ diêu), Lê Tất Điều dùng bút hiệu Kiều Phong (nhân vật trong Luc mạch thần kiếm), còn những người bạn Vũ Khắc Khoan thì lấy tên Hồng Thất Công (trong Anh hùng $x a$ điêu) đặt biệt hiệu cho Vũ vì Vũ cũng uống rượu say sưa như nhân vật này, Nguyên Sa lấy bút hiệu Hư Trúc (nhân vật trong Luc mach thần kiếm), Vũ Đức Sao Biển lấy bút hiệu Mạc Đại tiên sinh (Tiếu ngạo giang hồ), v.v." (Trần Lê Hoa Tranh 2009).

\subsection{5. Độc giả hứng thú với truyện tình}

Song song với tiếp nhận truyện Tàu, độc giả thành thị miền Nam, nhất là nữ giới, còn rất hứng thú với truyện tình. Loại truyện này có cả một truyền thống tiếp nhận trước đó.
Ngay từ năm 1925, Tùng Lâm trên Công luận báo đã nhận xét: "Xã hội ta hiện giờ, phần nhiều lại ưa đọc tiểu thuyết tình bất kì chuyện gì, bất kể lối văn gì, miễn cho có chuyện tình là ưa đọc lắm" (Võ Văn Nhơn và cộng sự 2015: 93). Một số hiện tượng văn học ái tình bán chạy, ăn khách như: tiểu thuyết thấm đẫm sắc màu hiện sinh sống gấp, yêu vội của Chu Tử (Yêu, Ghen, Loạn, Sống), Hoài Điệp Tử (Trái cấm), Thế Uyên (Tiền đồn, Ngoài đêm), Lê Xuyên $\left(V o^{\circ}\right.$ thày Hương), Nguyễn Thị Thụy Vũ (Mèo đêm, Đêm nay và mãi mãi); Túy Hồng (Vết thuoong dậy thì), Hoàng Đông Phương (Vòng tay học trò), v.v. hay các tập thơ diễm tình của Nhật Tuấn, v.v.. Chưa bàn đến chất lượng văn học hay giá trị thẩm mĩ, những tái trình hiện về chuyện tình trai gái, đời sống tình yêu, tình dục cởi mở, mãi dâm và bạo lực, v.v. đã có hấp lực đối với một bộ phận độc giả trẻ, và tầng lớp bình dân Sài Gòn. Việc độc giả tiếp nhận và tỏ ra yêu thích các tác phẩm này là một hiện tượng có tính tự nhiên của sinh hoạt văn nghệ Sài Gòn trong bối cảnh văn hóa Âu Mỹ đã và đang lấn át văn hóa dân tộc. Trong số các hiện tượng tiểu thuyết diễm tình thu hút mãi lực của độc giả nói trên, đáng chú ý nhất là hiện tượng Chu Tử, một cây bút vốn bị dán nhãn là "suy đồi", "phản động". Tác giả Quốc Chính nhận định như sau trong Tin Sách số 20 (tháng 2/1964): "Hiện tượng đáng chú ý nhất trong năm là hiện tượng Chu Tử. Chúng tôi đã trình bày hiện tượng này trong số trước. Một điều đáng nói thêm là ngoài yếu tố "đang ăn khách", Chu Tử còn gặp thêm một điều may: các nhà xuất bản ghen tức lẫn nhau nên ganh đua nhau dành dật tác phẩm của $\mathrm{Chu}$ Tử. Chắc chắn là truyện của Chu Tử còn bán chạy được khá lâu nữa, cho tới khi nào các nhà xuất bản chán hay mệt 
trong việc tranh dành không mấy lợi lộc này" (Phạm Việt Tuyển 1973: 14).

Đầu năm 1972, hiện tượng Quỳnh Dao đã tái khởi động cho một cơn bộc phát, một cuộc đua ráo riết về bản quyền và dịch thuật các sáng tác của Quỳnh Dao khắp các nhật báo miền Nam. Sau quá trình quảng cáo "rùm beng", tiếp nhận ồ ạt, hiện tượng Quỳnh Dao nhanh chóng lụi tàn, không tạo được một cơn sốt kéo dài như hiện tượng Kim Dung. Có thể giải thích điều này với ba lí do cơ bản. Hiện tượng Quỳnh Dao là sự tiếp nối khuynh hướng tiếp nhận truyện diễm tình vốn đã được một số nhà văn, nhất là nữ giới khơi mở từ trước đó với mối quan tâm thường trực của họ về phụ nữ, nữ quyền, chẳng hạn như: Nguyễn Thị Vinh, Linh Bảo, Minh Đức Hoài Trinh cho đến Nhã $\mathrm{Ca}$, Túy Hồng, Nguyễn Thị Hoàng, Nguyễn Thị Thụy Vũ, Trùng Dương, Lệ Hằng. Vì thế, hiện tượng Quỳnh Dao là "món ăn" vốn đã trở nên ngồn ngộn, ứ tràn trên "bàn tiệc" văn chương thời điểm đó. Sự thay đổi thị hiếu thẩm mĩ của độc giả thành thị nữ mới nổi diễn ra đầy chóng vánh. Họ có xu hướng chạ theo thị trường sách báo phổ thông (trình bày màu sắc, hình ảnh bắt mắt) và các hình thức giải trí hấp dẫn, thời thượng và đa dạng hơn (chớp bóng, kịch nghệ, tivi, v.v.). Ngoài ra, chiến sự ngày càng khốc liệt, không khí loạn lạc, lo âu "leo thang" khiến cuộc sống ngày càng trở nên khó khăn, bế tắc, do đó nhu cầu đọc và mãi lực của độc giả bị giảm sút. Từ sau năm 1973, độc giả có xu hướng quan tâm đến chiến sự, chính trường - những vấn đề có tính tồn vong thay vì đắm chìm trong những câu chuyện [tình] tưởng tượng.

Nhìn chung, độc giả chủ yếu của phân khúc văn học này là nữ giới. Họ có xu hướng thích những câu chuyện tình mùi mẫn, éo le, lâm li, bi đát, hoặc những câu chuyện có ý thức giải nam quyền/ phụ hệ. Họ chủ yếu là các bà nội trợ rảnh rỗi đọc trong khi chờ chồng đi làm về, hay các bà tiểu thương ở các chợ đọc lúc vắng khách, cũng có thể là các thiếu nữ mới lớn đang yêu, hay các quý cô học đòi đọc theo trào lưu. Tuy nhiên, một bộ phận độc giả khác đáng chú ý nhất và cũng chiếm số lượng lớn nhất, theo Võ Phiến, là hạng người đọc "mới nổi” tham gia vào sinh hoạt văn chương đô thị nhờ quá trình thị dân hóa, và cũng nhờ sự hiện diện và tiêu sài dịch vụ của đông đảo binh lính Mỹ tham chiến: "Người ta có những lời nói khinh bạc về một vài hạng độc giả mới: hạng "các em", hạng "sến"... Thật ra, các cô thợ may, thợ uốn tóc, các cô bán hàng, các cô cậu trong những gia đình làm công, làm thợ... đều có thể thuê Kim Dung, Quỳnh Dao về giải trí, để nói năng cho hợp thời thức" (1974: 21). "Sự thăng tiến giả tạo vội vã của tầng lớp cần lao thành thị” đã tác động không nhỏ đến sinh hoạt văn chương miền Nam. Vấn đề này tôi sẽ trình bày cụ thể hơn ở phần sau.

\subsection{6. Đọ văn hoc thị truờng nhu là cách thive vurọt thoát thưc tại}

Lý giải về sự lên ngôi của dòng văn học giải trí, tác giả Đoàn Thêm cho rằng: "Cuộc đời càng khó khăn, càng làm ăn một cách mệt nhọc, càng cần những giờ phút khuây khỏa, và tìm vui sống" (1963: 46). Trong suốt 21 năm, không khí sinh hoạt miền Nam luôn trong tình trạng phong bế, chao đảo. Cuộc sống ngày càng khó khăn đã làm nảy nở trong lòng người ham muốn được lãng quên. Vì thế mà, có thể coi dòng văn học thị trường: tiểu thuyết trinh thám, phiêu lưu, $\mathrm{du}$ kí, nhất là truyện Tàu, truyện tình, v.v. là một thứ "văn chương thoát ly", một phương cách để tìm quên thực tại. Vì thế, theo Nguyễn Mộng Giác, tác giả của văn học thị trường cũng là người "sản xuất ảo giác" (1972a: 49). Còn theo cách nói giàu hình ảnh và hàm ý mỉa mai của Nguyên $\mathrm{Sa}$, đó là thứ "bài tiết rỉ ra", thứ "chỉ còn đủ sức làm đầy thêm cho cuộc sống, vốn dư dả sung túc 
của thị dân ưu đãi, tô điểm thêm một tiếng cười khà, một tiếng vỗ đét vào vế khi trà dư tửu hậu" (Nguyễn Mộng Giác 1972a: 50). Đây cũng là hệ quả của việc nhà văn quá dễ dãi khi chiều theo thị hiếu số đông của độc giả, dẫn dụ họ vào "những thế giới mê hoặc huyền ảo, thế giới của chàng hào hoa và nàng diễm lệ, yêu nhau giữa khung trời mờ ảo của sương, trong gian phòng ngập khói thuốc lá và men rượu nồng". Những loại hình tiểu thuyết này làm khuây khỏa tinh thần, kích thích trí tưởng tượng của độc giả để họ tạm quên đi thực tại chán ngán của kiếp nhân sinh. Do đó, hệ lụy của văn học diễm tình, hay dòng văn học kéo độc giả vào không gian viễn mơ đã bị phê phán kịch liệt.

\section{2. Độc giả của văn học nghệ thuật: "Ham đọc, hiếu học, ua suy nghĩ"}

Đây là kiểu độc giả trí thức hay như cách diễn đạt "ham đọc, hiếu học, ưa suy nghî" (Võ Phiến 1974: 21) của ông Nguyễn Đình Vượng, chủ trương tạp chí Văn để định vị kiểu độc giả văn học nghệ thuật. Theo Võ Phiến, trong suốt thời gian từ 1954-1964, kiểu độc giả này đã làm nên tiếng tăm cho các tờ Sáng tạo, Thế kỷ 20, Văn nghệ, các sách của Quan Điểm, Giao Điểm, với các tác giả như Thanh Tâm Tuyền, Mặc Đỗ, Mai Thảo, Dương Nghiễm Mậu, v.v.. Một kiểu ngôn ngữ "thời thượng" gắn với đặc tính chung của kiểu độc giả này đó là: "suy tư", "dằn vặt", khắc khoải", "hoang mang" và "hiện hữu", v.v.. Đối tượng độc giả này đa phần là giới trí thức có trình độ văn hóa cao, và nhất là công chức, sinh viên và học sinh. Trước làn sóng tiếp nhận văn học thị trường ồ ạt (Kim Dung, Quỳnh Dao, truyện diễm tình) được dịch giả, nhà văn và hệ thống xuất bản phát hành hậu thuẫn, thao túng và chiều lòng thị hiếu độc giả, văn học nghệ thuật và độc giả của nó dần dần bị thu hẹp đến mức tưởng chừng như "mất dạng" (Võ Phiến 1974: 21).

\subsubsection{Tiền đề cho sự hình thành độc giả của văn học nghệ thuật}

Sự gia tăng về số lượng và trình độ của độc giả trí thức đến từ nhiều nguồn. Trước năm 1954, trí thức ở miền Nam khá đông đảo, phần lớn được đào tạo dưới nền giáo dục của Pháp. Sau biến cố chính trị 1954, cuộc di cư vào Nam dưới tên gọi Chiến dịch con đuờng đến tư do (Operation Passage to Freedom) của hơn một triệu người di dân từ miền Bắc, bao gồm lực lượng trong hệ thống chính quyền của thực dân Pháp, hàng chục vạn giáo dân, nhà kinh doanh, công chức, văn nghệ sĩ, kĩ sư bác sĩ, v.v.. Trong khi đó, ở miền Nam có khoảng 150.000 cán bộ, chiến sĩ, học sinh miền Nam tập kết ra Bắc (Nguyễn Đình Lê 2010: 6-7). Ngoài ra, chính sách chiêu hồi của chính phủ $\mathrm{VNCH}$ nhằm khuyến khích, lôi kéo các thành phần vốn ủng hộ cách mạng (Mặt trận Dân tộc Giải phóng miền Nam Việt Nam, Việt Nam Dân chủ Cộng hòa) thì nay đi theo tư tưởng được gọi là chính nghĩa VNCH, phục vụ cho chính thể $\mathrm{VNCH}$.

Ở các đô thị, thị xã lớn như Đà Nẵng, Huế, Buôn Mê Thuột, Đà Lạt, Sài Gòn, Cần Thơ, v.v. sự ra đời và ngày càng lớn mạnh của các trường, phân viện đại học, cao đẳng gắn với các trung tâm học thuật, văn hóa, và hệ thống báo chí văn nghệ đa dạng, v.v. đã dần đến sự hình thành của một bộ phận đông đảo độc giả là giới trí thức thành thị: văn nghệ sĩ, giới giáo chức và sinh viên đại học, cao đẳng, v.v.. Theo Đoàn Viết Hoạt, số lượng sinh viên ở miền Nam ngày càng đông. Năm học 1954-1955 chỉ có tổng số 2.145 sinh viền trên toàn miền Nam, đến năm học 1962-1963 đã lên tới 17.929, năm 1964 tổng số sinh viên là 23.662, và năm 1969 số này tăng lên tới 46.257 (1972: 83). Tương ứng với số lượng tăng của sinh viên, miền Nam cũng xuất hiện nhiều trường đại học. Trước năm 1963, ngoài Đại học Sài Gòn chỉ có thêm hai trường đại học khác 
mới được thành lập: Viện Đại học Huế và Viện Đại học Đà Lạt. Từ năm 1963 xuất hiện thêm 5 trường đại học mới (trong đó 4 trường đại học thuộc tư nhân và 01 trường đại học công - Viện Đại học Cần Thơ (Đoàn Viết Hoạt 1972: 83). Chỉ sau ngành luật, số sinh viên tốt nghiệp chuyên ngành văn từ 1954-1974 là 2010 (cử nhân), 58 (cao học) chiếm số lượng đông hơn cả các ngành khác (Khoa học, Y, Dược, Kiến trúc) (Trần Ngọc Định 1975: 18). Theo Nguyễn Đình Lê và cộng sự, năm học 1973-1974, sau ngành Luật, ngành Văn khoa thu hút nhiều sinh viên nhất với 26.673 người (2019: 287). Nhìn chung, sự hiện hiện đông đảo của sinh viên và các trường đại học đã góp phần nâng cao tri thức xã hội, tạo ra một lực lượng người đọc có tri thức nói chung.

Bên cạnh đó phải kể đến các chương trình văn hóa giáo dục của Mỹ như: gửi sinh viên Việt Nam di du học ở Mỹ, gửi các phái đoàn nhân viên giáo dục Việt Nam đi tu nghiệp và thực tế tại Mỹ, hỗ trợ cho các cơ sở giáo dục trong nước, v.v.. Các chính sách giáo dục, văn hóa của Mỹ nhằm "Mỹ hóa học đường", gây sức ảnh hưởng của Mỹ lên sinh hoạt văn hóa chính trị tại miền Nam đã có những kết quả nhất định. Do một bộ phận lớn trí thức thành thị miền Nam còn đang bị ảnh hưởng sâu đậm văn hóa Pháp cho nên những nỗ lực của đế quốc Mỹ không đạt được như kì vọng. Nhìn chung, những tiền đề trên đã góp phần hình thành một lượng độc giả có trình độ kiến văn, có khả năng thẩm bình văn chương. Tuy nhiên, bộ phận độc giả này chỉ là một thiểu số ở thành thị gồm học sinh sinh viền và một phần nhỏ trí thức xã hội khác (Nguyễn Văn Trung 1966: 18).

\subsubsection{Diện mạo của độc giả văn học nghệ} thuật

Có thể tạm dùng nhận định của nhà văn Thạch Lam để định vị diện mạo của kiểu độc giả này: "Hạng này là những người không lười trí, họ ưa suy nghĩ, tư tưởng và tìm tòi. Họ thờ phụng và theo đuổi cái đẹp, cái hoàn toàn. Họ biết thưởng thức một câu văn hay, một ý tưởng sâu sắc, và cảm thấy một cái thú vô song khi sắp bước vào tâm hồn của một nhân vật nào" (1941: 36). Cuộc phỏng vấn bạn đọc: Độc giả bây giờ đọc tiểu thuyết nào? khởi đăng trên Tạp chí Nghệ thuật từ số 36 đến 57/1966 có lẽ là một nỗ lực dài hơi nhất nhằm làm sáng tỏ diện mạo thực sự của tiểu thuyết và độc giả văn học miền Nam. Nhà văn Mai Thảo chủ bút tờ Nghệ thuật đưa ra tổng kết dựa trên những hồi đáp của bạn đọc về 5 câu hỏi ${ }^{1}$ gợi ý của toà soạn. Về độ tuổi và công việc, như tôi đã khẳng định trước đó, độc giả văn học nghệ thuật phần lớn là bộ phận học sinh sinh viên, giáo chức, văn nghệ sĩ và một bộ phận trí thức tiểu tư sản: "Phần lớn những bài trả lời đã đăng cũng như phần lớn những ý kiến toà soạn vừa nhận được, đều gửi đến từ những cửa trường, những phân khoa (...), anh chị em sinh viên học sinh là thành phần

\footnotetext{
15 câu hỏi đó là:

“i. Khi nói đến truyện, đến tiểu thuyết Việt Nam (kể cả những người viết truyện ngắn) bạn nghĩ tới tác giả nào trước hết?

ii. Bạn theo dõi một tác giả như thế nào? Chỉ qua các tác phẩm hay còn qua đời sống riêng? Bạn có đọc tất cả mọi tác phẩm của tác giả bạn thích không? Ví dụ có, thì bây giờ bạn thấy tác giả đó ra sao so với chính ông ta (hay bà, cô) từ khi bạn biết?

iii. Bạn quan niệm như thế nào về vai trò của văn chương: văn chương dùng để giải trí hay văn chương có một giá trị nào đối với chính bạn hoặc đối với xã hội? Hoặc văn chương chỉ có giá trị với chính nó? iv. Vậy theo quan niệm bạn vừa nói (ví dụ văn chương là để giải trí thì tiểu thuyết có đáp ứng được phần nào điều bạn mong mỏi ở nó không? Nếu có, nó đáp ứng được như thế nào và nếu không, nó đã thất bại như thế nào?

v. Bỏ ra ngoài mọi quan niệm trên và chỉ xét theo phần giá trị riêng của tác giả, xin bạn lập cho một danh sách 10 nhà văn mà bạn thích nhất.

Ngoài 5 câu hỏi này, bạn có thể phát biểu thêm những gì bạn muốn nói" (Tạp chí Nghệ thuật số 35: 7)
} 
hưởng ứng đông đảo và nồng nhiệt nhất" (Mai Thảo 1966: 10). Sở thich chung của họ là "những nhà văn mới, những nhà văn đang có nhiều tác phẩm được in ra, những nhà văn có mặt" (Mai Thảo 1966: 10). Điều này cho thấy độc giả có xu hướng quan tâm đến những vấn đề đương thời, và những cách biểu đạt mới trong nghệ thuật, "bạn đọc đứng về phía cái thế giới tiểu thuyết đang mở đường, đang tìm kiếm, đang thoát ly những chân trời tiểu thuyết cũ". Không những vậy, bạn đọc còn bày tỏ niềm thích thú với những thể nghiệm mà nhà văn tạo dựng, đồng hành cùng nhà văn trên hành trình đầy chông chênh của viết và đọc, sáng tạo và thưởng thức. Mai Thảo đánh giá cao trình độ của độc giả: “...Cuộc phỏng vấn đã đem lại cho nhà văn một phát giác kỳ thú: người đọc bây giờ đã lớn bổng lên. Và là những người đọc ý thức, những người đọc tự $\mathrm{do}$, không nằm trong khuôn mòn, không nói theo thành kiến" (Mai Thảo 1966: 31). Theo Mai Thảo, bạn đọc đã tái định nghĩa về khái niệm "tác phẩm". Với bạn đọc, "tác phẩm bây giờ khác với tác phẩm cổ điển ở điểm nó không còn mang tinh thần của một kinh thánh văn chương. Tác phẩm chỉ là một đất đai gặp mặt, từ đó người mở thêm những cửa ngõ và những chân trời mới cho nhận thức chủ quan của mình. Nói cách khác, tác phẩm chỉ là một động lực thúc đẩy và giúp đỡ con người trong khám phá bản thân và đời sống”. Mai Thảo đã đưa ra một sự phân biệt về hệ hình thẩm mĩ và tiếp nhận của độc giả văn học cổ điển và hiện đại. Từ đó, cho thấy bước chuyển đổi mới mẻ từ hệ hình văn học cổ điển sang hiện đại. Độc giả trở thành chủ thể tiếp nhận với trạng thái bất tín, hoài nghi về những sự thật được trình bày trong tác phẩm, thứ không còn là "kinh thánh" với một chân lí duy nhất nữa. Về thị hiếu của độc giả trí thức, phần lớn họ không đi theo/ đứng ngoài thị hiếu của số đông độc giả văn nghệ thị trường (mặc dù có một bộ phận độc giả trí thức say mê truyện Tàu), lựa chọn đọc của họ là những tác phẩm khiến họ phải suy nghĩ, trăn trở, thậm chí là dằn vặt. Sau năm 1954, độc giả của Nguyễn Mạnh Côn, Thanh Tâm Tuyền, Doãn Quốc Sỹ, Mặc Đỗ, Vũ Khắc Khoan, Mai Thảo là "những con người đầy ưu tư", "bận tâm về thời thế hoặc thắc mắc về vấn đề ý nghĩa cuộc sống, về đường lối chính trị, hoặc ít ra cũng băn khoăn theo dõi sự tìm kiếm một đường lối sáng tác..." (Võ Phiến 1974: 21). Tác phẩm không mang đến cho họ những giờ phút nghỉ ngơi khuây khỏa, ngược lại tác phẩm làm dấy lên trong tâm tư họ những chất vấn miên man về bản thể và tha nhân: "Đọc không còn là giết thì giờ. Đọc là tìm kiếm những thì giờ đã mất" (Viên Linh 1966: 19). Minh chứng rõ nhất cho những đặc điểm trên của độc giả trí thức đó là chuyên mục "Bạn đọc viết về những nhân vật tiểu thuyết V.N"2 khởi đi từ Nghệ thuật số 52 . Có thể coi chuyên mục này là một nỗ lực kéo dài với mục đích "để người viết đối diện người đọc”, người đọc trực tiếp trình bày, chất vấn với nhân vật và tác giả tiểu thuyết.

Độc giả trí thức đã tái định nghĩa "sự đọc" và "tác phẩm văn chương". Mai Thảo nhận định về một bộ phận độc giả mới của văn chương: "Đối với người đọc, cái mà người viết bây giờ đã thực hiện được, là đã đẩy được người đọc mình đến đứng chung với mình trên mặt điểm khởi hành mới, thỏa

\footnotetext{
${ }^{2}$ Các bài như: Tôn Thất Miên. 1966. "Một con người trong tác phẩm của Dương Kiền", Tạp chí Nghệ thuật số 52: 10, 32; Nguyễn Thúy. 1966. "Kẻ không muốn mất tích trong một tác phẩm của Thanh Tâm Tuyền". Tạp chí Nghệ thuật số 53: 4-5; Đỗ Tư Nhơn. 1966. "Về chuyến viễn du bí mật của chàng". Tạp chí Nghệ thuật số 54: 10-11, 22; Nguyên Anh. 1966. "Cô đơn thân phận trong truyện Nguyễn Đình Toàn". Tạp chí Nghệ thuật số 55: 10-11, 23; Đoàn Minh Hải. 1966. "Sợi dây, Duy Thanh tôi với Đạo". Tạp chí Nghệ thuật số 56: 10-11; Trương Văn Ngọc. 1966. "Chiến tranh và tai nạn qua nhân vật Michèle Gấm của Thụy Vũ”. Tạp chí Nghệ thuật số 57: 10$11,23$.
} 
thuận gia nhập với mình vào một hành trình mới, cũng cảm thấy cần thiết như mình là phải có những trải nghiệm mới, đưa tới những khám phá và những thực hiện mới. Nội dung tiểu thuyết hiện nay dồn đuổi người đọc ra khỏi cái tinh thần thưởng ngoạn bình yên hằng cửu là thái độ xưa cũ của người đọc trước những tác phẩm cổ điển. Tác phẩm cổ điển là những cuốn kinh thánh bằng văn chương. Đọc và tin. Giữa tác phẩm cổ điển, với tác giả cổ điển và người đọc là một trạng thái chấp nhận và thỏa thuận hoàn toàn về đời sống và cho chính bản thân người đọc. Đọc bây giờ khác. Đọc không còn đem lại yên ổn cho tâm hồn, mà trái lại, tiểu thuyết bây giờ bảo người đọc là cuộc đời không phải như vậy đâu, như trong những tác phẩm cổ điển. Bằng những lột trần tàn nhẫn, bằng những đào xâu xuống những tầng đáy chưa khám phá của tiềm thức và tâm linh, tiểu thuyết chúng ta hiện nay đã thành công một phần nào trên ý hướng đem lại cho người đọc một đòi hỏi mới, tạo cho người đọc một nhận thức mới. Nói khác, ở người đọc đã có một thái độ mới về tiêu chuẩn thưởng ngoạn. Qua tiểu thuyết của chúng ta hiện nay, người viết và người đọc đã gặp nhau trên một đất đứng chung. Đó là những băn khoăn đòi xét lại” (BBT 1965: 7). Nhận định này của Mai Thảo cho thấy những chuyển biến của lối sáng tác, thậm chí là lí luận, phê bình văn học lấy người đọc làm trung tâm (reader-response criticism) thay vì lấy văn bản làm trung tâm (text-centred criticism) trước đó.

Độc giả, nhất là một bộ phận độc giả trẻ sinh sau năm 1945 muốn tìm hiểu các sáng tác tiền chiến và văn hóa tiền chiến. Từ năm 1967, một bộ phận độc giả trí thức thành thị có xu hướng tiếp nhận di sản của Tự lực văn đoàn, nhất là Khái Hưng, một hiện tượng văn hóa đọc ngoại lệ, nằm ngoài quán tính thị trường. Việc độc quyền xuất bản tác phẩm của Khái Hưng kể từ cuối năm 1963, cùng với trào lưu phục hồi ánh hào quang một thời của Tự lực văn đoàn nói riêng và văn thơ tiền chiến nói chung (từ năm 1967)³), lại được bổ trợ bằng thực tế là một số tác phẩm của Khái Hưng như: Hồn buớm $m o$ tiên, Nửa chùng xuân, Tiêu sơn tráng sĩ đều hiện diện trong chương trình quốc văn của học sinh trung học... đã tạo điều kiện cho Nhà xuất bản Văn nghệ phát hành và tái bản được một số lượng lớn tiểu thuyết của Khái Hưng. Trước đó, một bộ phận tác giả (Duy Thanh và cộng sự 1960) đã chất vấn lại/ nhìn lại các giá trị của Tự lực văn đoàn nói riêng và văn hóa văn học thời tiền chiến nói chung.

Trong giai đoạn từ năm 1966-1968, trước sự lấn át của dòng văn học thị trường, dự án sách phổ thông (sách hay, dễ đọc, in với số lượng nhiều) của Nhà xuất bản Văn là một nỗi lực để kháng cự lại sự lấn lướt của dòng văn học thị trường và sự suy tàn của dòng văn học nghệ thuật. Sự thành công của dòng sách phổ thông cho thấy văn học "nghiêm chỉnh" vẫn có chỗ đứng dù khiêm nhường trong thị trường tiêu thụ cạnh tranh khốc liệt. Ông Nguyễn Đình Vượng chủ Nhà xuất bản Văn đã thương thảo nhuận bút thấp với tác giả cốt để có giá bán rẻ hơn, từ đó kích cầu độc giả mua sách. Một số tác phẩm văn học miền Nam của Nhà xuất bản Văn bán chạy là: Tuổi nước độc (Dương Nghiễm Mậu), Người về đầu non (Võ Hồng), Gia đình tôi (Duy Lam), Khuôn mặt (Thanh Tâm Tuyền), Chị em Hải (Nguyễn Đình Toàn), v.v.. (Nghê-Bá-Lí 1969c: 78-79).

\footnotetext{
${ }^{3}$ Xin xem thêm hai bài viết được đăng trên Tân văn: Nguyễn Hiến Lê. 1969. "Tình hình xuất bản từ biến cố Mậu Thân đến nay”. Tạp chí Tân văn số $16 \& 17$ : 1-11; và Mai Thảo. 1969. "Trước phong tào tái bản và làm sống lại văn thơ tiền chiến". Tạp chí Tân văn số 16\&17: 21-31
} 
3.2.3. Đọc văn hoc nghệ thuật chua trở thành một nhu cầu văn hóa cần thiết

Đọc văn học chưa trở thành một nhu cầu văn hóa có tính cấp thiết nếu so với nhật báo, hoặc so với các bộ môn nghệ thuật khác, chẳng hạn kịch nghệ và điện ảnh. Từ "văn học" ở đây là chỉ văn học nghệ thuật, văn học "nghiêm chỉnh", thuộc về một nghệ thuật vốn không mang đến cho độc giả giây phút tiêu khiển và giải trí đơn thuần, ngược lại, nó đòi hỏi ở độc giả tính nhẫn nại, khả năng đồng hành cùng tác phẩm trên hành trình đầy chênh vênh, gian nan của sự đọc. Có chăng, văn học chỉ thực sự trở thành "món ăn tinh thần" đối với một bộ phận nhỏ độc giả: sinh viên (chủ yếu Văn khoa), giới văn nghệ sĩ, trí thức xã hội khác. Văn học nghệ thuật và độc giả của nó hoàn toàn bị lép vế, bị dồn đuổi vào "phần đất hẹp khiêm nhường vả lẻ loi” (Nguyễn Mộng Giác 1975: 30) trước sức mạnh thao túng của thị trường và làn sóng ngấu nghiến truyện Tàu, truyện tình hay truyện trinh thám, kinh dị của đại đa số quần chúng. Thực vậy, theo Nguyễn Mộng Giác (1972a: 49), mặc dù hầu hết các tiểu thuyết ở miền Nam trước khi được in thành sách đều có tiền kiếp của chúng là feuilleton trên các nhật báo, nhưng phần lớn đều là tiểu thuyết võ hiệp, diễm tình nặng tính giải trí, chiều theo số đông thị hiếu độc giả. Trong khi đó, các tạp chí văn nghệ, trước đó là Sáng tạo, rồi Văn, Trình bày, Khởi hành, Vấn đề... hầu như "chìm trong sự hờ hững của quần chúng, mất địa vị, mất ảnh hưởng...” (Võ Phiến 1972: 42).

Theo Nguiễn-Ngu-Í, người thuật lại "Buổi nói chuyện về tình trạng bế tắc trong ngành tiểu thuyết Việt Nam", một trong những nguyên nhân đẩy tiểu thuyết Việt Nam đương thời đi vào bế tắc đó là ý thức đọc sách, văn hóa đọc của độc giả còn rất thấp (1962: 109). Điều này còn được minh chứng qua số liệu thống kê lượt mượn sách tại các thư viện vào năm 1961. Số lượt mượn sách của người Việt rất thấp so với một số nước khác có cùng tỷ lệ dân số (Đoàn Thêm 1963: 49). Ngoài ra, thống kê các ấn phẩm được phát hành nhiều nhất giai đoạn trước còn cho thấy số lượng tiêu thụ sách văn học còn khá thấp so với sách giáo khoa, sách kĩ năng sống, sách giáo dục mới, sách học làm người, sách tri thức bỏ túi, sách giải trí vốn bán rất chạy và được hàng loạt các nhà sách đua nhau ấn hành. Thống kê đến năm 1968, các cuốn: Đắc nhân tâm, Nghệ thuật nói truớc công chúng, Kim chi nam cho hoc sinh, v.v.. là những đầu sách bán chạy nhất của Nhà xuất bản Nguyễn Hiến Lê (Nghê-Bá-Lí 1969a: 38). Với Nhà xuất bản An Tiêm, hai cuốn Hố thẳm của tu tương (9.000 bản), Tự do đầu tiên và cuối cùng (Krishnamurti, Phạm Công Thiện dịch 4.000 cuốn, đang in lại) liên quan đến tác giả và dịch giả Phạm Công Thiện bán chạy nhất (Nghê-Bá-Lí 1969a: 112). Hoặc với Nhà xuất bản Lá Bối, các tựa sách của thiền sư Thích Nhất Hạnh được tái bản với số lượng lớn, chẳng hạn cuốn Nói với tuổi hai mươi được tái bản 3 lần với tổng in 21.000 cuốn, cuốn Đạo Phật ngày nay được tái bản 3 lần, cuốn Bông hồng cài áo được in 70.000 bản (Nghê-Bá-Lí 1969b 66). Một ấn phẩm dịch khác thuộc dòng Sách giáo dục mới được đông đảo thanh thiếu niên yêu thích đó là cuốn Tâm hồn cao thượng (Edmond de Amicis) được Nhà xuất bản Sống mới tái bản liên tục đến lần thứ 14 (Vũ Hạnh và cộng sự 2008: 391). Nhìn chung, các đầu sách bán chạy nói trên phần lớn là sách dịch, trong đó đáng chú ý là dòng sách self-help. Dòng sách này luôn chiếm lĩnh thị trường sách miền Nam và nhìn vào thực tiễn ngày nay, đây cũng là dòng sách được tiêu thụ nhiều nhất toàn cầu. 


\section{4. Độc giả và tác động của văn hóa xã hội}

\subsection{Người nông dân: Tù̀ quá trình ngoại biên hóa đến trung tâm hóa sinh hoạt văn chuong}

Một bộ phận độc giả bình dân của văn chương tiêu khiển ở các đô thị lớn được hình thành từ quá trình thị dân hóa nông dân. Người nông dân bị cưỡng bức, bị ngoại biên hóa (marginalization) khỏi môi trường đồng ruộng để lánh trú và mưu sinh ở đô thị. Từ đây, họ trở thành thị dân, bán thị dân với nhu cầu tiêu dùng văn chương như là thú tiêu khiển.

\subsubsection{Tù quá trình ngoại biên hóa...}

Đại đa số nông dân miền Nam bị gạt ra bên lề sinh hoạt nghệ thuật và báo chí. Từ năm 1955, dưới sự kiểm soát và chống phá của chính quyền $\mathrm{VNCH}$, Thành ủy, Khu ủy Sài Gòn cũng như giới văn nghệ sĩ yêu nước khó có thể gây dựng được một bộ phận độc giả quần chúng văn học hiện thực xã hội chủ nghĩa lớn mạnh, thống nhất như ở miền Bắc. Vì thế, các nhóm thực thể độc giả có tính lai ghép như: "độc giả quần chúng", "độc giả chiến sî", "nhà văn - chiến sî" dường như chỉ gắn với bộ phận độc giả và tác giả của dòng văn học chống Pháp và chống $M y ̃$ (trong điều kiện hoạt động ở các vùng giải phóng) và hầu như xa lạ với sinh hoạt văn chương ở các đô thị miền Nam. Mặt khác, độc giả quần chúng công nông binh, không phải là chủ thể tiếp nhận chính của nền văn hóa văn nghệ miền Nam. Hầu hết các nhà xuất bản, tạp chí văn học nghệ thuật đều đặt trụ sở tại các đô thị lớn, hướng đến nhu cầu của hai đối tượng độc giả chính yếu: độc giả của văn học thị trường và văn học nghệ thuật. Ngay cả với báo chí, người nông dân cũng không phải là đối tượng độc giả tiềm năng của nó. Đánh giá về mối quan hệ giữa người nông dân và báo chí Sài Gòn, tác giả Dương Kiền cho rằng: "Báo chí là phương tiện tuyên truyền mạnh mẽ nhất tại thành thị, nhưng chỉ tại thành thị mà thôi. Một người nông dân không thể tìm thấy một điều gì liên quan đến họ trong một tờ báo. Người nông dân $\mathrm{X}$. tại một làng $\mathrm{Y}$. đọc một tờ báo xuất bản tại Sài Gòn cũng dửng dưng như chúng ta đọc một tờ báo xuất bản tại Mã Lai chẳng hạn, mặc dù làng Y. chỉ cách Sài Gòn chừng vài chục cây số và tờ báo $X$. dành cả 4 trang cho tình hình Việt Nam, chiến cuộc tại Việt Nam hay một vụ "xuống đường" tại Sài Gòn $(\ldots)$ Chúng ta chưa hề có một tờ báo của nông dân. Chúng ta chỉ có những tờ báo của một thiểu số trí thức trưởng giả (ngay cả tờ báo mà quý bạn cầm trên tay đây). Trong khi chúng ta có biết bao điều để nói với nông dân và họ cũng có biết bao điều để nói với chúng ta" (1965: III-IV). Văn học, nhất là văn học thị trường gắn chặt với nhật báo nhưng nhật báo (nhất là các nhật báo chống cách mạng) cũng chỉ được phân phối đến các quận huyện tỉnh lị trong vùng tạm bị chiếm, khó có thể đi sâu hơn vào các vùng nông thôn, cao nguyên miền Nam. Nhật báo là vậy, còn tạp chí văn nghệ hầu như không có vai trò và ảnh hưởng gì đến người nông dân. Với họ, tất cả những gì không phải là "miếng cơm", "manh áo" đều là xa xỉ phẩm. Thân phận văn hóa đọc của người nông dân được hình thành và có vai trò quan trọng trong sinh hoạt văn nghệ đô thị kể từ sau quá trình di dân vào các đô thị lớn ở miền Nam do tác động của chiến tranh và thời cuộc.

\subsection{2. Đến quá trình trung tâm hóa sinh hoạt văn chuong}

Từ giữa thập niên 1960 trở đi, độc giả văn học miền Nam có sự thay đổi về thành phần, khuynh hướng thẩm mĩ, độ tuổi và nghề nghiệp. Một bộ phận lớn độc giả bình dân mới nổi là kết quả của quá trình trung tâm hóa sinh hoạt văn chương đô thị.

Khởi đi từ Chiến tranh cục bộ (19651967), phương lược của Mỹ và chính quyền 
Sài Gòn là bình định vùng nông thôn, nhất là nông thôn đồng bằng ven các đô thị. Trong cuộc chiến tranh xâm lược Việt Nam, Mỹ đã sử dụng 14 triệu tấn bom đạn, rải chất độc hóa học khắp vùng nông thôn miền Nam (Nguyễn Đình Lê và cộng sự 2019: 187). Cuộc chiến khốc liệt giữa chính quyền Sài Gòn và cách mạng để giành giật từng địa bàn nông thôn đã đẩy sinh mệnh và cơ nghiệp của người nông dân vào cảnh "màn trời chiếu đất”. Từ giữa năm 1965, làn sóng di cư từ vùng chiến sự ác liệt đến các vùng ít ác liệt hơn hoặc đến các khu ven đô, đô thị diễn ra với tần suất liên tục và số lượng đông đảo. "Trong Chiến tranh cục bộ và nhất là thời kỳ Việt Nam hóa chiến tranh, theo quan sát của báo chí nước ngoài, tính đến năm 1971 đã có 6 triệu dân nông thôn bỏ ruộng vườn, quê hương đi nơi khác. Trong số này có 4,2 triệu dân sơ tán vào thành thị" (Nguyễn Đình Lê và cộng sự 2019: 166). Trung bình cứ mỗi người nông dân sẽ phải sơ tán 2 lần trong đời (Nguyễn Đình Lê và cộng sự 2019: 188). Với mục đích lánh nạn và kiếm sống, hàng triệu người nông dân đã đổ vào các thành phố lớn ở miền Nam, "chiến tranh đã ép người nông thôn thành thị dân" (Nguyễn Đình Lê và cộng sự 2019: 74), từ đó, đưa tỉ lệ dân số đô thị từ 17-18\% trước 1960 lên khoảng 40\% vào 1973 (Nguyễn Đình Lê và cộng sự 2019: 190-191). Có thể nói, thực trạng các đô thị ngày càng gia tăng về dân số là hiện tượng phổ biến của quá trình chuyển đổi từ văn minh nông nghiệp sang văn minh cơ giới, từ nông nghiệp sang công nghiệp.

Hiện tương di dân này còn được hậu thuẫn bởi sự hiện diện đông đảo của binh lính Mỹ và quân đồng minh, nhất là trong giai đoạn 1965-1972. Bên cạnh nguồn viện trợ khổng lồ rót vào chính thể $\mathrm{VNCH}$, lực lượng binh lính Mỹ, hiện thân sinh động của văn hóa Mỹ với mức lương cao và tư tưởng "FTA" (Fun Travel Adventure: vui vẻ - du lịch - phiêu lưu) đã tiêu dùng và hưởng thụ các dịch vụ văn hóa giải trí (quán rượu, ổ điếm, vũ trường, rạp chớp bóng, sân khấu, v.v.) ở miền Việt Nam. Vì thế, xã hội miền Nam rất cần một lực lượng lao động bình dân thành thị để tham gia vào các quá trình phục vụ, tiêu thụ và vận hành. Những người nông dân bị "bứng" khỏi đồng ruộng, phải lên thành phố mưu sinh, nơi có điều kiện kiếm tiền dễ hơn, cho phép họ cải thiện đời sống vật chất và tinh thần. Bộ phận thị dân mới nổi này nhanh chóng thích nghi và hòa nhập với nền kinh tế hàng hóa và văn hóa tiêu dùng. Theo Nguyễn Mộng Giác, độc giả mới nổi này có đặc điểm chung như sau: "Những người bỏ đồng ruộng tản cư lên phố tìm được việc làm, con cái được ăn học, đời sống gia đình được thăng tiến. Sự trù phú giả tạo ở các thị trấn ảnh hưởng đến tinh thần lớp thị dân mới mẻ. Họ nhiễm dễ dàng các thói xấu của kẻ mất gốc, chạy đi tìm những hình thức họ tưởng là kiểu mẫu mới, liều lĩnh, nhẹ dạ, đua đòi học làm sang. Số độc giả mới rất đông đảo này có một tâm tình khác hẳn với số thị dân cũ và số công chức học sinh lâu nay là độc giả trung thành của tạp chí văn học. Họ dễ dàng tin theo những lời quảng cáo, mê chuộng thời trang, lo lắng sợ bị chê là quê mùa. Do đó sách báo ở trình độ phổ thông (loại báo phụ nữ, sân khấu, cải lương, bói toán, trinh thám, v.v.) bán rất chạy ở các thành thị” (Nguyễn Mộng Giác 1972b: 28-29). Họ trở thành bộ phận độc giả chủ lực của văn học thị trường, đọc văn chương như một thú tiêu khiển. "Sự thăng tiến giả tạo vội vã của tầng lớp cần lao thành thị" mới nổi này đã tác động mạnh mẽ đến sinh hoạt văn chương miền Nam. Việc nuông chiều dễ dãi thị hiếu giải trí của bộ phận độc giả này khiến cho yếu tố thương mại ngày càng lấn lướt yếu tố nghệ thuật, đẩy văn học nghệ thuật "vào phần đất hẹp khiêm nhường và lẻ loi" (Nguyễn Mộng Giác 1975: 30). 


\section{2. Độc giả tiếp nhận đa dạng văn hóa Xô viết}

Ngoài ra, cũng có một số tờ báo với tư tưởng đối lập cách mạng hoạt động sôi nổi như: Ngôn luận (chủ bút Hà Đức Minh), Chính luận (chủ bút Đặng Văn Sung) (hai tờ báo này của người Bắc Kỳ di cư, nổi tiếng ở Sài Gòn), nhật báo Sóng thần, tuần báo Đời (chủ bút Chu Tử), Trắng đen (chủ bút Việt Định Phương), v.v.. Khác với độc giả quần chúng ở miền Bắc, vốn chịu ảnh hưởng sâu đậm của văn hóa Xô viết (nhất là văn hóa mác xít), độc giả miền Nam lại có xu hướng tiếp nhận điều độ, cởi mở và tự do hơn, bao gồm cả văn hóa phản ý thức hệ Xô viết. Có thể thấy, ở miền Bắc, hầu hết các tác giả văn học Xô viết đoạt Giải thưởng Quốc tế Lenin, Giải thưởng Nhà nước Liên Xô, Giải thưởng Nhà nước Liên bang Nga, v.v. đều được điều phối để trở thành những xuất bản phẩm chủ lực, được tái bản nhiều lần với số lượng lớn, được phát hành và tuyên truyền rộng khắp. Những tác phẩm chính trị này đóng vai trò quan trọng trong việc truyền bá ý thức hệ mác xít. Độc giả miền Nam tiếp nhận đa dạng, trong đó phải kể đến các tác giả chống cộng quốc tế, phản chủ nghĩa xã hội vốn xa lạ với độc giả miền Bắc, ví dụ công trình Thần đêm $u$ ám (tập hợp các bài viết bị gán nhãn là "chính trị phản động" của Richard Crosman, Raymond Aron, Ignazio Silone, Richard Wright, Arthur Koestler, v.v.); Các tiểu thuyết Số không với vô tận (Arthur Koestler), Độc hành, Lối thoát cuối cùng, Giò̀ thứ hai mưoi lăm (Constantin Virgil Gheorghiu), v.v.. Theo Trần Trọng Đăng Đàn, việc dịch và xuất bản các tài liệu sách báo có tính phản mác xít, chống cộng nằm trong guồng máy "chiến tranh tâm lý" (2015: 37) của chính quyền Sài Gòn. Nhìn chung, việc tiếp nhận văn học Xô viết của độc giả miền Nam có phần cởi mở, đa dạng hơn và không mang tính phong trào và đại chúng so với độc giả miền Bắc.

\section{3. Độc giả tiếp nhận ồ ạt văn hóa văn học phương Tây}

Trong khi độc giả miền Bắc tiếp nhận chủ yếu văn hóa văn học phe xã hội chủ nghĩa (Xô viết [nhất là Nga], Trung Quốc) (Lê Quốc Hiếu 2020: 56), độc giả miền Nam lại có thiên hướng tiếp nhận đa dạng, tự do văn hóa văn học nghệ thuật phương Tây (điển hình là Pháp, Mỹ, Anh), trong đó phải kể đến khuynh hướng văn học bị dán nhãn là "suy đồi", "phản động". Theo Trần Trọng Đăng Đàn, năm 1976, thống kê sách dịch ở miền Nam như sau: "Dịch và giới thiệu tác phẩm của các tác giả Pháp: 499 tên sách; Tiếp theo đó là của các tác giả Trung Quốc, bao gồm cả lục địa Đài Loan và Hồng Kông: 358 tên sách của các tác giả Hoa Kỳ: 273 tên sách; Của các tác giả Nga và Xô viết: 120 tên sách; Của các tác giả Anh: 97 tên sách; Của các tác giả Nhật: 71 tên sách; Của các tác giả Ý: 58 tên sách; Của các tác giả Đức: 57 tên sách; cùng 156 tác phẩm dịch và công trình, bài viết về văn học nghệ thuật của các nước khác" (2015: 40). Trước hết, số lượng sách Pháp được dịch thuật và tiếp nhận ở miền Nam Việt Nam cho thấy quán tính tiếp nhận và ảnh hưởng sâu đậm nền văn hóa này của độc giả văn học vốn có từ hơn một thế kỉ. Kể từ khi xâm lược miền Nam, Mỹ đã thực hiện nhiều sách lược để Mỹ hóa văn hóa Việt Nam, giảm bớt dần ảnh hưởng của văn hóa Pháp trong sinh hoạt tinh thần của người dân miền Nam. Mặt khác, trào lưu sách dịch nhộn nhịp đến mức lạm phát thị trường chữ nghĩa. Kể từ năm 1972, có lẽ trong bối cảnh o ép của không khí chiến tranh tao loạn, chính sách kiểm duyệt gắt gao hơn trước, tình trạng rệu rã của sáng tác, xuất bản, phát hành văn học trong nước, cho nên sách dịch là cách tốt nhất để đáp ứng cung cầu của thị hiếu độc giả, khai thác nguồn tiềm năng sằn có (một đội ngũ dịch giả chuyên nghiệp, nguồn bản thảo dồi dào, hấp dẫn), đồng thời giúp các 
nhà sách gắng gượng sống sót qua cơn bĩ cực. "Cuối năm 1972, ngồi kết toán, những nhà phát hành đã ước lượng rằng tỷ lệ sách dịch thuật của 1972 tăng lên khoảng từ 60\% đến $65 \%$ tổng sản lượng ấn loát phẩm $(. .$.$) .$ Sang tới năm 1973, tỷ lệ nói trên còn vọt cao hơn nữa, đạt đến mức xấp xỉ 80\%" (Đào Trường Phúc 1973: 33). Đánh giá về hiện tượng nổi lên của sách dịch trong năm 1972, 1973, Đào Trường Phúc lí giải: “... Trong mấy năm qua, càng lúc, đà sáng tác của những nhà văn Việt Nam càng có vẻ chậm lại, và hiểu theo một cách nào đó thì dần dà người ta đã có dịp ghi nhận sự chênh lệch giữa mức cung và mức cầu của món ăn tỉnh thần, hay nói cách khác, sự thiếu thốn tác phẩm so với mức độ đòi hỏi của độc giả. Vì sao các nhà văn Việt Nam viết ít đi và viết chậm lại? Vấn đề ấy được ràng buộc với nhiều yếu tố tế nhị: hoàn cảnh sinh hoạt cá nhân, sự khó khăn trong ngành xuất bản và phát hành, những trở ngại về kiểm duyệt..." (1973: 36-37). Nhìn chung, độc giả văn học miền Nam có xu hướng lựa chọn sách vằn học ngoại, "sách nhập cảng" thay vì văn nội hóa, có lẽ là bởi sách ngoại mở ra những chân trời kiến thức rộng lớn, đa dạng về văn hóa nhất là văn hóa Âu Mỹ vốn đang được khuyến khích để "ăn sâu bén rễ" trong sinh hoạt tinh thần ở miền Nam Việt Nam.

Theo Nguyễn Hiến Lê (1969: 5), thái độ "chán ngán" tính "vật chất" và "nổi loạn" của văn hóa văn minh phương Tây là hậu quả của việc tiếp nhận ồ ạt và thừa mứa, từ đó, độc giả có xu hướng tìm về các giá trị tinh thần phương Đông và văn hóa dân tộc. Đây là lí do vì sao, từ năm 1967, một loạt sách dịch và khảo cứu được ấn bán liên tục và bán khá chạy: sách của Khrisnamurti (Ấn Độ), Hermann Hess (Đức), hai bộ Kinh dịch, sách biên khảo về nếp sống cổ Việt Nam, tế lễ, phong tục, tôn giáo của Đỗ Bằng Đoàn, Toan Ánh, v.v.. Cũng theo Nguyễn Hiến Lê, độc giả có xu hướng tìm hiểu về văn hóa, lịch sử của các dân tộc nhược tiểu đang cùng cảnh ngộ thuộc địa.

\subsection{Văn hóa đọc xuống cấp}

Từ năm 1967, tình trạng xuống cấp của văn hóa đọc, sự "lạc lõng", "mất kết nối" giữa ba giới: tác giả - phê bình - người đọc trong hệ thống sản xuất, định hướng và tiếp nhận văn học trở thành vấn đề nhức nhối trong sinh hoạt văn học miền Nam. Không khí chiến tranh tao loạn tác động sâu rộng đến khả năng sáng tác của nhà văn, năng suất phát hành của nhà xuất bản, và mãi lực của độc giả. Chẳng hạn, biến cố Mậu Thân (1968) làm phá sản, điêu đứng, và tê liệt một số tạp chí và nhà xuất bản ở miền Nam, đời sống của người dân ngày càng khốn khó: "Mải lo trăm chuyện: vật giá cứ hiên ngang leo thang mà đồng bạc cứ âm thầm xuống giá, lo làm sao đủ tiểu cho tới cuối tháng; Hết lo thiếu sữa, thiếu gạo, bây giờ lại lo thiếu đường; Lo tin tức con cháu ngoài mặt trận, lại lo bị giật xách tay ở giữa đường, lo điều chỉnh tờ khai gia đình, lo địch dọa tấn công mạnh vân vân, vì vậy tinh thần lúc nào cũng căng thẳng, chỉ mưu tính cuộc sống hằng ngày cũng đủ mệt, và lần lần chúng cũng muốn quên cơn ác mộng Tết Mậu Thân năm ngoái" (Nguyễn Hiến Lê 1969: 1). Sức mua và nhu cầu đọc của độc giả bị giảm sút nghiêm trọng do tác động nặng nề của chính sách thuế "kiệm ước". Thuế má và vật giá leo thang khiến nhiều nhà xuất bản phải "nằm im chờ thời", thậm chí đi đến phá sản.

Nhìn vào sinh hoạt năm 1967, Thanh Lãng (1967: 16-17) đã chất vấn tình trạng "cô đơn", "lẻ loi", "độc thoại" của cả ba giới, phải chăng điều này đã dẫn đến việc "giới tiêu thụ văn đã chẳng thèm tiêu thụ sản phẩm văn nội hóa mà chỉ say mê xài đồ ngoại hóa, đặc biệt đồ Tàu: hiện tượng độc giả đam mê truyện Tàu chẳng phải thể hiện cái tâm lý khinh đồ nội hóa đấy ư?" Cùng 
chung quan điểm này, Huỳnh Như Phương (2015: 33) nhận định về hậu quả của dòng văn học thị trường: "Tính chất thương mại hóa của báo chí và xuất bản đã gây ra hậu quả tầm thường hóa văn học như hiện tượng đổ xô viết tiểu thuyết feuilleton, tranh đua dịch sách về tính dục, đề cao quá đáng Kim Dung, Quỳnh Dao; Nhưng đặt trong bối cảnh thị trường, thì điều đó cũng dễ hiểu khi văn học trở thành một hàng hóa tiêu thụ đáp ứng bữa ăn tinh thần đa dạng của độc giả...".

Văn hóa đọc càng xuống cấp trầm trọng hơn trong bối cảnh lên ngôi của các hình thức giải trí đại chúng như nhật trình, điện ảnh và cải lương. Điện ảnh, một loại hình nghệ thuật đại chúng đầy mới mẻ, phản ánh những chủ đề hấp dẫn và kích thích như tình dục và bạo lực, đã trở thành một hình thức sinh hoạt tinh thần ưu thế hơn cả so với văn học. Từ năm 1969 đến đầu thập niên 1970, sau một thời kì dài "bất lực", "câm nín" trước sự lên ngôi và thống soát của điện ảnh ngoại nhập, điện ảnh nội địa đã có những cú "trở mình" và ghi nhận những thành công vang đội với Chiều kỷ niệm (1969), Loan mắt nhung (1970), Chân trời tím (1971) (Mai Thảo 1970: 4). Ngoài ra, giai đoạn này còn phải kể đến một xu hướng tái sinh văn học và nối dài hành vi đọc của độc giả thông qua hiện tượng điện ảnh hóa cải lương và tiểu thuyết. Các phim được cải biên từ tiểu thuyết của Văn Quang, Nguyễn Đình Toàn, Mai Thảo, Ngọc Linh, Nguyễn Thị Hoàng, Duyên Anh, Viên Linh, v.v. có thể xem như là những "hậu kiếp" của tiểu thuyết nguồn (source novel), nối dài và chuyển hóa quá trình đọc và xem của độc giả/ khán giả. Bộ phim Chân trời tím đạt số lượng xem kỉ lục, cao nhất ở VNCH và chưa từng bị soán ngôi với 31 triệu lượt xem, tiếp đó là phim Xin dì̀ng bỏ em với 29,8 triệu lượt xem và Biển động với 27,8 triệu lượt xem (Vũ Hạnh
1971: 33-34). Trước sự lên ngôi của điện ảnh thân xác và bạo lực, tình trạng xuống cấp của văn hóa đọc ngày càng đáng báo động. Theo thống kê của linh mục Nguyễn Ngọc Lan, trong số 41 phim được chiếu trong 1 ngày ở Sài Gòn đã có đến 35 phim "đồi trụy" với chủ đề chính là về "tình dục" và "bạo lực" (Phan Đắc Lập 1974: 54). Những tái trình hiện về văn hóa truyền thống dân tộc đang ngày càng bị lấn át bởi những tái trình hiện về đời sống văn hóa Âu Mỹ.

\section{Kết luận}

Nhìn chung, hệ hình độc giả của văn học miền Nam khác biệt so với hệ hình độc giả văn học miền Bắc. Điều này là do hệ quả của những khác biệt về thể chế chính trị và văn hóa. Dưới sự chi phối của ý thức hệ xã hội chủ nghĩa, văn học trở thành "mặt trận", tác giả và độc giả văn học (chủ yếu quần chúng công nông binh) trở thành "chiến sî" cách mạng; việc sáng tác - phát hành - tiếp nhận đều nằm trong kế hoạch, đường lối của Đảng và được đặt hàng và kiểm soát thông qua các thiết chế khác nhau từ trung ương đến địa phương (Lê Quốc Hiếu 2020: 46); khắp miền Bắc là sự hiện diện của các huyền thoại văn hóa xã hội chủ nghĩa: hiệu sách nhân dân, thư viện nhân dân, v.v... Theo quan điểm của lí thuyết gia mác xít người Pháp Althusser, có thể nói, "các cấu trúc đàn áp/ý thức hệ" (repressive/ideological structures) hoặc "các công cụ ý thức hệ của nhà nước" (state ideological apparatuses) (Barry 2009: 158) đã được áp dụng triệt để trong văn hóa văn học miền Bắc, để định hướng văn hóa văn nghệ. Khác với nền văn nghệ quần chúng ở miền Bắc, văn nghệ miền Nam, về cơ bản, phát triển khá tự do và chịu tác động to lớn của quy luật thương mại hóa văn nghệ. Ở 
miền Nam, trước sự lên ngôi của các hình thức văn học thị trường, dòng văn học nghệ thuật và cộng đồng độc giả "ham đọc, hiếu học, ưa suy nghĩ” của nó vẫn luôn hiện hữu dù mờ nhạt, "khiêm nhường" trong sinh hoạt văn nghệ đô thị. Bài viết đã trình bày một vài nét khái quát về hai kiểu độc giả văn học ở miền Nam giai đoạn 1954-1975: độc giả của văn học thị trường và độc giả của văn học nghệ thuật, đặt trong mối quan hệ với các thiết chế văn học và văn hóa. Bài viết chưa có điều kiện khảo sát đối tượng độc giả văn học thiếu nhi và độc giả nữ đặc biệt là khuynh hướng nữ tính hóa văn chương từ sau thập niên 1960. Các lí thuyết phê bình như: Lý thuyết tiếp nhận, Nữ quyền luận và Hậu thực dân, v.v. cũng chưa được ứng dụng để "đọc sâu" các bình diện về giới tính, chủng tộc, thuộc địa có liên quan trực tiếp đến người đọc.

\section{Tài liệu trích dẫn}

Barry Peter. 2009. Beginning theory: An Introduction to Literary and Cultural Theory, Third edition, Manchester University Press, 384 pages.

BBC. 2018. "Báo Sóng Thần chống tham nhũng trước

1975 "

(https://www.bbc.com/vietnamese/vietnam-

43911897). Truy cập tháng 5 năm 2020.

BBT.1965. "Nhận định về tiểu thuyết Việt Nam hiện nay”. Tạp chí Nghệ thuật 9: 6-8, 27.

Bình Nguyên Lộc. 1969. "Thời vàng son của nghề xuất bản tại Sài Gòn”. Tạp chí Tân văn số 16\&17: 13-19.

Duy Thanh, Mai Thảo, Ngọc Dũng, Nguyễn Sỹ Tế, Thanh Tâm Tuyền, Thái Tuấn, Tô Thùy Yên, Trần Thanh Hiệp. 1960. "Nhìn lại văn nghệ tiền chiến ở Việt Nam". Sáng tạo (bộ mới) 4: 1-16.

Dương Kiền. 1965. "Một chính sách thông tin văn hóa mới”. Tạp chí Văn Học 40: I-VII.

Đào Trường Phúc. 1973. "Sách dịch thuật trong năm qua". Tạp chí Bách Khoa thời đại số 402\&403: 33-37.
Đoàn Thêm. 1963. "Tác giả - Độc giả - Nhà phê bình" (tiếp theo). Tạp chí Bách Khoa số 147: 41-49.

Đoàn Viết Hoạt. 1972. "Cơn sốt đại học miền Nam” (tiếp theo). Tạp chí Tu tuoơng 2: 81-98.

Hiếu Chân. 1967. "Bàn về tiểu thuyết võ hiệp". Báo Tin văn số 16.6.1967. Dẫn theo Trần Lê Hoa Tranh. 2009. "Bước đầu tìm hiểu về "hiện tượng Kim Dung” tại Việt Nam" (http://khoavanhoc-

ngonngu.edu.vn/home/index.php?option $=$ com $_{-}$ content \&view $=$ article \&id $=214:$ bc-u-tim-hiu-vqhin-tng-kim-dungq-ti-vit-nam\&catid=64:vnhc-nc-ngoai-va-vn-hc-so-sanh\&Itemid=108). Truy cập tháng 7 năm 2020 .

Huỳnh Như Phương. 2015. "Chiến tranh, xã hội tiêu thụ và thị trường văn học miền Nam 19541975". Tạp chí Nghiên cứu văn học số 4: 2740.

Lê Quốc Hiếu. 2020. "Bước đầu tìm hiểu độc giả của văn học hiện thực xã hội chủ nghĩa ở Việt Nam giai đoạn 1945-1975". Tạp chí Nghiên cưu Văn học số 10 (584): 45-61. https:// doi.org/10.5281/zenodo.5774589

Lý Chánh Trung. 1970. "Văn hóa võ khí bảo vệ

dân tộc." Trang 912-923 trong sách Nhìn lại một chăng đường văn học. Nghiên cứu - Sưu tầm - Tuyển chọn Trần Hữu Tá. Thành phố Hồ Chí Minh: Nhà xuất bản Tp Hồ Chí Minh.

Mai Thảo. 1966. "Ghi nhận thứ nhất về ý kiến bạn đọc đối với tiểu thuyết bây giờ". Tạp chí Nghệ thuật 42: 10, 31.

Mai Thảo. 1969. "Trước phong tào tái bản và làm sống lại văn thơ tiền chiến”. Tạp chí Tân văn 16\&17: 21-31.

Mai Thảo. 1970. "Những nét lớn về sinh hoạt nghệ thuật miền Nam 1970”. Tạp chí Vấn đề 42\&43: 1-11

Nghê-Bá-Lí. 1969a. "Qua những cuộc đàm thoại với một số nhà xuất bản ở thủ đô, thử kiểm điểm: Tình hình xuất bản sách trước và sau biến cố Tết Mậu Thân 1968". Tạp chí Bách Khoa thờ đại 289: 35-40,107-114.

Nghê-Bá-Lí. 1969b. "Qua những cuộc đàm thoại với một số nhà xuất bản ở thủ đô, thử kiểm điểm: Tình hình xuất bản sách trước và sau biến cố Tết Mậu Thân 1968". Tạp chí Bách Khoa thời đại 293: 63-71. 
Nghê-Bá-Lí. 1969c. "Qua những cuộc đàm thoại với một số nhà xuất bản ở thủ đô, thử kiểm điểm: Tình hình xuất bản sách trước và sau biến cố Tết Mậu Thân 1968". Tạp chí Bách Khoa thời đại số 294: 75-80.

Nguiễn-Ngu-Í thuạtt. 1962. "Buổi nói chuyện về tình trạng bế tắc trong ngành tiểu thuyết Việt Nam. Tạp chí Bách Khoa 128: 108-110.

Nguyễn Đình Lê. 2010. Lịch sủ Việt Nam (19541975). Hà Nội: Nhà xuất bản Giáo dục.

Nguyễn Đình Lê (Chủ biên), Phan Hải Vân. 2019. Biến chuyển xã hội Việt Nam 1954-1975. Hà Nội: Nhà xuất bản Khoa học xã hội.

Nguyễn Hiến Lê. 1969. "Tình hình xuất bản từ biến cố Mậu Thân đến nay". Tạp chí Tân văn số 16\&17: 1-11.

Nguyễn Hiến Lê. 1972. "Sau 18 năm tiếp xúc với người Mỹ, vài suy nghĩ về phong trào về nguồn”. Tạp chí Bách Khoa số 361\&362: 5366.

Nguyễn Mộng Giác. 1972a. "Nhìn lại 15 năm văn nghệ miền Nam". Tạp chí Bách Khoa 361\&362: 40-51

Nguyễn Mộng Giác. 1972b. "Nghĩ về một vài hiện tượng trong tình hình chữ nghĩa 1972”. Tạp chí Bách Khoa 385\&386: 23-30.

Nguyễn Mộng Giác. 1975. "Nghĩ về thơ, truyện 1974”. Tạp chí Bách Khoa 421\&422: 25-33.

Nguyễn Quang Duy. 2015. "Nhìn lại báo chí thời Đệ nhị Cộng hòa" (https://www.bbc.com/vietnamese/forum/2015/ 09/150911_nguyenquangduy_baochi_vnch).

Truy cập tháng 5 năm 2020.

Nguyễn Văn Lục. 2014. "20 năm văn học dịch thuật miền Nam 1955-1975" (https://nguoitinhhuvo.wordpress.com/2014/12 103/20-nam-van-hoc-dich-thuat-mien-nam1955-1975-nguyen-van-luc/). Truy cập tháng 6 năm 2020.

Nguyễn Văn Trung. 1965. "Thử đặt lại vấn đề văn hóa ở Việt Nam ngày nay”. Tạp chí Văn Học số 40: 8-13, 89-105.

Nguyễn Văn Trung. 1966. "Thảo luận về thực trạng văn nghệ miền Nam". Diễm Châu ghi. Tạp chí Nghệ thuật 53: 18-19, 30.

Nguyễn Văn Trung. 2001. "Văn học trong vòng tay chính trị”. Tạp chí Văn học số 179: 15-41.
Phạm Việt Tuyển. 1972. "Người cầm bút từ năm 1954 tới nay". Tạp chí Bách Khoa 378: 9-16, 62-63.

Phan Đắc Lập. 1974. "Đồi trụy, một đặc điểm của văn học thực dân mới ở miền Nam". Tạp chí Văn học số 148: 54-64.

Sơn Nam. 1966. "Bàn về hiện tượng sách báo", Đồng Nai văn tập số 7, tháng 7\&8/1966. Dẫn lại theo Lũ Phương. 1967. Mấy vấn đề văn nghệ. Sài Gòn: Nhà xuất bản Trình bày.

Tùng Lâm. 1925. Công luận báo số 45 ngày 21/3/1925. Dẫn theo Võ Văn Nhơn, Nguyễn Thị Phương Thúy. 2015. "Văn học thị trường ở thành phố Hồ Chí Minh". Tạp chí Nghiên cưu văn hoc số 9: 89-104.

Thạch Lam. 1941. Theo giòng: vài ý nghĩ về văn chương. Hà Nội: Nhà xuất bản Đời nay.

Thanh Lãng. 1967. "Người 67 nhìn vào phê bình 67”. Tạp chí Văn Hoc 74: 20-36.

Thanh Nam. 1982. "Hai mươi năm viết văn làm báo ở Sài Gòn”. Tạp chí Văn, Hoa Kỳ số 2 tháng 8-1982.

Trần Lê Hoa Tranh. 2009. "Bước đầu tìm hiểu về "hiện tượng Kim Dung" tại Việt Nam" (http://khoavanhoc-

ngonngu.edu.vn/home/index.php?option =com_ content \&view $=$ article \&id $=214:$ bc $-u$-tim-hiu-vqhin-tng-kim-dungq-ti-vit-nam\&catid=64:vnhc-nc-ngoai-va-vn-hc-so-sanh\&Itemid=108). Truy cập tháng 9 năm 2020.

Trần Ngọc Định. 1975. "Nền giáo dục đại học thực dân mới của Mỹ ở miền Nam Việt nam trước ngày giải phóng". Tạp chí Nghiên cứu lịch sủ số 165: 17-25.

Trần Trọng Đăng Đàn. 2015. Văn học trong cuộc đấu tranh tư tưởng tại miền Nam thời kỳ 1945 - 1975. Hà Nội: Nhà xuất bản Khoa học Xã hội.

Trùng Dương. 2018. "Báo Sóng Thần chống tham nhũng trước 1975" (https://www.bbc.com/vietnamese/vietnam43911897). Truy cập tháng 7 năm 2020.

Viên Linh. 1966. "Ghi nhận chót". Tạp chí Nghệ thuật số 45: 18-19, 31.

Võ Phiến. 1972. "Nhìn lại 15 năm văn nghệ miền Nam”. Tạp chí Bách Khoa số 361\&362: 39-42. 
Võ Phiến. 1974. "Có gì mới trong sinh hoạt văn nghệ". Tạp chí Bách Khoa thời đại số 421\&422: 19-24

Võ Văn Nhơn, Nguyễn Thị Phương Thúy. 2015. "Văn học thị trường ở thành phố Hồ Chí Minh". Tạp chí Nghiên cứu Văn học số 9: 89104.
Vũ Hạnh. 1971. "Vài nét về sinh hoạt văn nghệ trong năm 71”. Tạp chí Bách Khoa 361\&362: 31-35.

Vũ Hạnh, Nguyễn Ngọc Phan. 2008. Văn học thời kỳ 1945-1975 ở thành phố Hồ Chí Minh. Hồ Chí Minh: Nhà xuất bản Tổng hợp Thành phố Hồ Chí Minh. 